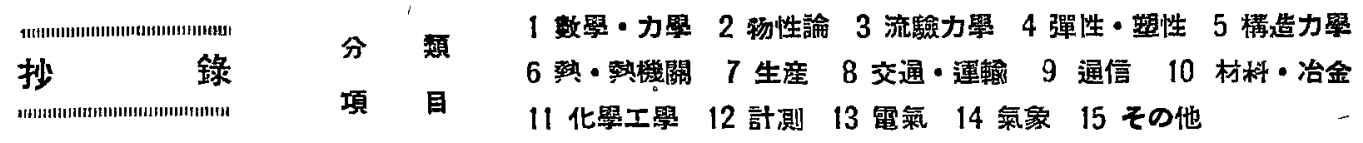

\section{數 學}

前立一次方程式の家次近以解の誤差評價， Collatz， L. ZA M M ，22 卷, 1942，357/361，聯立一次方程式を $2 X X$

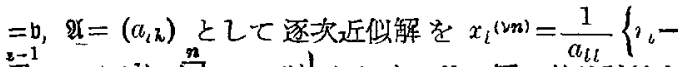

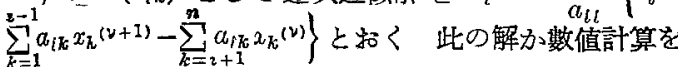
行引に際して便利てあるのは對角線要素 $a_{i l}$ か他の要素 $a_{i k}$ に比して十分に大きい時てある。 $a_{l}$ ，かての條件を

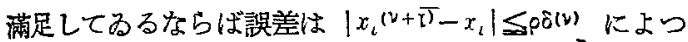
て見積るととか出來る。但 $\mathrm{P}=M_{i} H_{a x} \frac{b_{i}}{\left|a_{i}\right|-b_{i}}, b_{i} \stackrel{n}{=} \sum_{k=1}^{n} 1$ $a_{2 x}|<| a_{l \imath} \mid \delta(v)$ は一つ前の近似解との差の最大，郎方 $\delta(v)=\mathrm{M}_{\mathrm{ax}}\left|x_{\imath}(v+1)-x_{2}^{(n)}\right|$ でる。更に例 ๖の聯立方程式をとつて，ガウスの得換を用いて隨伊行 列 $\mathfrak{A}^{\prime}$ を左から乘じて新しい方程式原 $\mathfrak{B X}=\subseteq \mathfrak{B}=\mathfrak{A} / \mathfrak{X}$. $\mathfrak{S}=\mathfrak{U}^{\prime} \mathrm{t}$ に變換しても必ずしも主對角線要素加十分に大 きくならないととを示す。(㭊山壽夫)

\section{彈 性・塑 性}

国弧切缺を有する帶板の引張力, Stresses in a Notched Strsp under Complession, Chnh Bingling, J App Mech 14 卷 4 號，1947/12，275/280，帶板の幅を $2 b$ と 乙座標を適當にとり圓の中心か $(0, \pm 1)$ となるやらに する。 $x$ 軸は帶板の長さの方向にとり圆の牛俓を入て表 はす。切缺のない時の解は $X_{00}=\frac{1}{2} T b^{2} y^{2}$ てする。別に

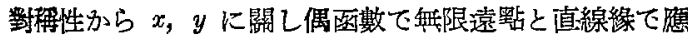
力を與へない重調和函數 $X_{\alpha} k ， X^{\prime}{ }_{2 \pi}(k=0,1,2)$ を 作り之を $X_{00}$ に加へ切缺周遑の應力か零となるやうに 保數を調節する。こふに $X_{2}$ は $(0, \pm 1)$ に單位丢線 力が作用する時の解

$$
X_{a}=\frac{\Sigma b}{\pi} \int_{0}^{\infty}\left\{\frac{\sin h m}{m^{2}} \frac{(1+m \cot m) \cos m y-m y \sin h m y}{\sinh 2 m+2}\right.
$$
- $\left.\frac{1}{2 m^{2}}\right\} d m$ を $x$ にいて微分して得られる $X_{2}=$ $-\frac{2 \pi(-1)^{k}}{b(2 k+1)}, \frac{\partial^{2 h+2} X_{a}}{\partial x^{2 k+2}}, X_{2}^{\prime} k$ は $(0, \pm 1) k(-x)$ 方向に單位切線力の作用する特の解 $X_{b}=-\frac{2 b}{\pi} \int_{0}^{\infty}$ $\frac{\cos m y-y \cos h m \sin m y}{m(\sin h 2 m+2 m)} \sin m x d m$ を $x$ について微分し

て得られる $X_{2 k}^{\prime}=-\frac{2 \pi(-1)^{k}}{b(2 k)}, \frac{\partial^{2 k+1} X b}{\partial x^{2 k+1}}$ でる。郎ら
$X=X_{00}+b^{2} T \sum_{k=0}^{\infty}\left(A_{2 h} X_{2 h}+B_{\sim} X^{\prime} 2 k\right), x+\imath y+\imath=i 1 e^{-\imath \theta}$

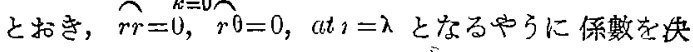

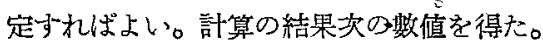

\begin{tabular}{c|cccc}
\hline$\lambda$ & 0 & 025 & 05 & 10 \\
\hline 䍊力集中係数 & 9065 & 2378 & 1801 & 1000 \\
\hline
\end{tabular}

この值は, WahI and Beeuwkes 及び Frocht の實驗 結果と大體傾向は一致してるるか，若干大なる值を與へ てるる。(筧㡽久一)

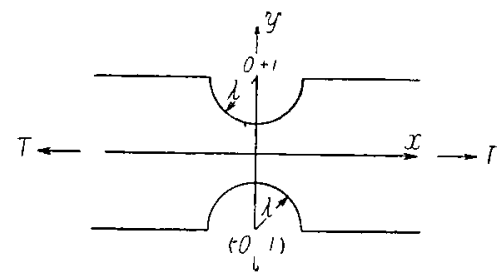

第 1 圖圆弧切缺を有する帶板

中空断面の捻りの一數值解法, A Numen real Solution for the Tor suon of Hollow Seclion; E C Colin and N M Newmark, J Ap $\bar{p} 1$ Math 1947/12, 318/315, 捻りの篧力列数を用ら九怯捻りの間題性 $\Delta \phi=-2 G \theta$ を 周邊に於て $\phi=一$ 定て解くことに䁎着する。今全斷面を 一邀〉なる正方形の網目て覆へばこの方程式は $\phi=\frac{\phi(x, y+\gamma)+\phi(x, y-7)+\phi(x+7, y)+\phi(x->y)}{4}$

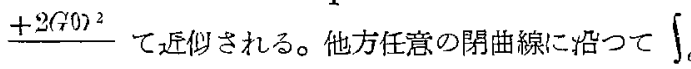
$\frac{\partial \phi}{\partial n} d s=2 G \theta A_{c}$ て为るから積分路を孔の周题に取り， 孔の周爆の $\phi$ を $\phi_{0}$ ，そ机隣る節敤の $\phi$ を $\phi_{2}$ て表 はすと左圐は近似的に $\left.\int_{a} \frac{\partial \phi}{\partial n} d s=\sum_{2}\left(\frac{\phi_{0}-\phi_{l}}{\lambda}\right)\right\rangle=n \phi_{0}-$ $\sum \phi_{i}$ と憲ける。とれらを聯立に解けはよい。Relaxatron Method による时性

$F_{r}=F_{r-1}-\left[n\left(\Delta \phi_{0}\right)-\sum\left(\Delta \phi_{\ell}\right)\right]$ 力剩餘荷重 (residual load)となる。(㗭津)

平面昰, 平面䜃力の集中力問題, $A$ Goncent, ated $F_{0}$ rce Problem of Plane Stran or Plane Stress, A E Green, J App Mech、14达 3 晩，1947/9，246，長短

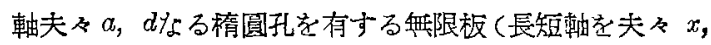


$y$ 軸に一致させてとる。 $) の(0, \pm \boldsymbol{b})$ なる點に，士y.方向 に集中力か作用与る場合の二光元本面問題を取找つてる る。 $z=x+\imath y=F(s)=c \cos (s+i \alpha), \zeta=\xi+\imath n$ とし棈圓の 周邊は $n=0$ に對㟲するすのとすれは $a=c \cosh \alpha, b=$

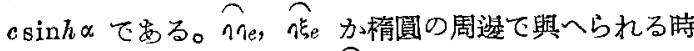
には real pa)t of $V(\zeta)=-\overbrace{n}$ e, imaginas y pant of $W(\zeta)$

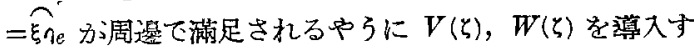
れは，笕の周邊の合力か零なる場合の一般解は次の式の real part て與へら机る。

$$
\begin{gathered}
\widehat{\xi \xi}=-V(\zeta)-W(\zeta)-W(\zeta) \bar{F}(\zeta] / \bar{F}^{\prime}(\zeta)-\frac{1}{2} \\
\left\{V^{\prime}(\zeta)+W^{\prime}(\zeta)\right\}\{\bar{F}(\zeta)-\bar{F}(\zeta)\} / \bar{F}^{\prime}(\bar{\zeta}) \\
\hat{n}=-V(\zeta)-W(\zeta)+W(\zeta) \bar{F}^{\prime}(\zeta) \bar{F}^{\prime}(\bar{\zeta})+\frac{1}{2} \\
\left\{V^{\prime}(\zeta)+W^{\prime}(\zeta)\right\}\{\bar{F}(\zeta)-\bar{F}(\bar{\zeta})\} / \bar{F}^{\prime}(\bar{\zeta}) \\
\xi \eta=-2 W(\zeta) \bar{F}^{\prime}(\zeta) / \overline{F^{\prime}}(\bar{\zeta})-\frac{1}{2}\left\{V^{\prime}(\zeta)+W^{\prime}(\zeta)\right\} \\
\{\bar{F}(\zeta)-\bar{F}(\bar{\zeta})\} / \bar{F}(\bar{\zeta})
\end{gathered}
$$

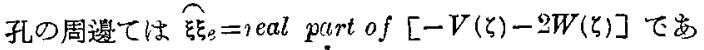
る。 $V(\zeta), W(\zeta)$ 唖限遠點て零になるやう, 又 $\bar{F}^{\prime}(\zeta)$

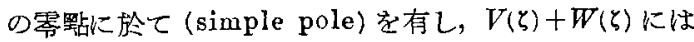
pole かないゃうに選学。問題の集中力の場合には $V(\zeta)$ $=-\frac{\imath P}{a \pi} \frac{\sin \zeta}{\cos \zeta} \frac{\cosh 2 \alpha+1}{\cosh 2 \alpha-\cos ^{2} 2 \zeta}, \quad W(\zeta)=-\frac{P}{a \pi} \frac{\cosh \alpha}{\cosh \alpha}$ $\frac{\cosh 2 \alpha+1}{\cosh 2 \alpha-\cos 2 \zeta}$ を探用すればよく，

$\widehat{\xi}_{e}=\frac{2 P b}{\pi a^{2}} \frac{\cos h 2 \alpha+1}{\cos h 2 \alpha-\cos \Xi \xi}$, 長軸の端ては $\frac{a \pi}{P} \widehat{\xi}_{e}=\frac{2 a}{b}$, 長 軸に沿つては, $a \leqq x>\infty, x=c \cos h(n+\alpha), 0 \leqq n<\infty$, $\widehat{\widehat{x} x+\hat{y}=} \quad 2 P \cosh \alpha$

$x x+y y=\frac{3 P \cosh \alpha}{u \pi \cosh \eta \sinh (\eta+\alpha)}$,

$\widehat{y y}-\widehat{2 x}=\frac{P \sinh 2 \alpha}{a \pi \cos h n \sin h^{2}(1+\alpha)}\left\{\frac{1}{\cos h n}\right.$

$\left.-\frac{\sin h \eta 0 n \sin (n+\alpha)}{\sin h(\eta+\alpha)}\right\}$ となる。參考交献として

"Streas Systems sn Isotropue and Aestrapue plates" A E Green, Pro Roy Toc London, Series A, vol 184, 1915 年，231 页力揚㤃られてるる。(瞩侓)

横方向に補强された板の㮍断挫屈；Buckling of Transorse Stiffened Plate under Shear, Tsun Kuei Wagn, Sian, I Appl Mech 14 愁 3 號，1947/12，269/274; 橫方向に補强された單純支持の矩形板の周邊一樣分布の 剪斷力による挫屈を取圾つてある。補强材は曲け゚のみを 考慮する。有限矩形板ては $w=\sum \sum A_{m n} \sin \frac{m \pi x}{a} \sin \frac{n \pi y}{b}$, “無限長の帶板では $w=A \sin \frac{\pi y}{b} \sin \frac{\pi}{s}(x-\alpha y)$ と撓形を假 定しェネルギー法て解き，末尾にその結果を圖表にし設 計の便に供してはる。(篊律)

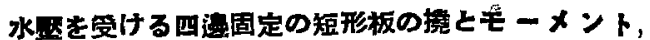
Deflection and Moments of a Reetangular Plate Clamped on all Edges and Hydrostatic Pressure. Ezra G 0dley, J Appl Math. 14 卷 4號, 1947/12, 239/295; 級數法と Marcus 法により問題を解數値計算結果の比 較を行つてるる。級教法ては $w=w_{1}+w_{2}+w_{3}+w_{4}$ と就く。 こっに $w_{1}$ は $q$ による撓, $w_{2}, w_{3} w_{4}$ は夫く $r= \pm \frac{b}{2}$, $y=0, y=a$ の潋上の任意モーメント分布による撓をい づれる周邊支持の條件で解いたるのてある。次にwに周 邀固定の條件を課し， $w_{2} ， w_{3} ， w_{4}$ 中に含を机る未定常 を聯立方程式から求める。Mareus 法ては $\xi=\frac{\tau}{b / 2} \eta=$ $y / \alpha, w=K X(\xi) \cdot Y(n)$ と挌く。か小る $w$ 老生ずる荏重 分布は

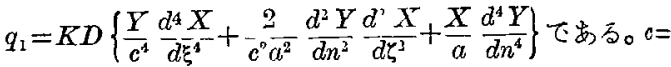
$\frac{b}{g}$ 。 $X$ か分つてるる时 $Y$ 求めるには $\pi_{x}=2 \int_{0}^{c} q_{1} d x=$ $2 k D c \int_{0}^{1} \Delta^{0} w d \xi$ acturl lo ld $\pi_{x}=2 \int_{0}^{r} q d x$ と等置し $n_{x}$ $=\int_{0}^{1} \frac{d^{4} X}{d \xi^{4}} d \xi, \quad{ }_{i x}=\int_{0}^{1} \frac{d^{2} X}{n \xi^{2}} d \xi \quad S_{x}=\int_{0}^{1} X d \xi, K=\frac{q_{0} C^{4}}{D \mu_{\mu_{x}}}$ 特けば

$Y=n-\left(A \sin \gamma n \sinh \mu n+B \sin \eta n \cosh \mu n+C_{\cos }\right\rangle n \sinh \mu n$

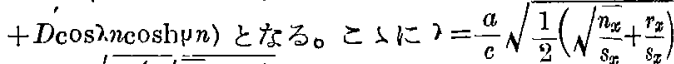
$\mu=\frac{a}{c} \sqrt{\frac{1}{2}\left(\sqrt{\frac{n_{x}}{s_{x}}}-\frac{r_{x}}{s_{x}}\right)}$ てある。更に境界條件を入れるど

$A, B, C, D$ の值か定る。同樣に $Y$ が刵つてるる時の $X$ の表示も $\pi_{y}=\int_{0}^{a} \eta_{0} \frac{y}{a} d y$ を利用して求められるから $X_{0}$ に適當な形を假定し逐次近似法て解く。この解法流 解を $v=K X Y$ の形に制限してるるから逐次近似も高度 に進めてる正解にはならぬ。乙か乙數值計算結果は級教 解によるるのと大體一致してるる。モーメントは Marcus 法が若干大きな值を與へるが，撓は殆えど一致して るる。末尾算 Marcus 法による数值計算過程か揭餺し てある。(䈑津)

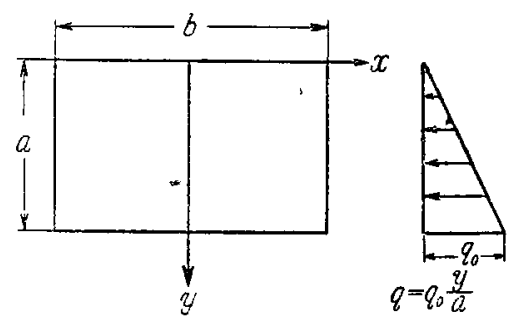

第 2 圆水原を受ける四遥固定の短形板

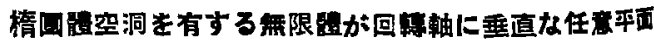




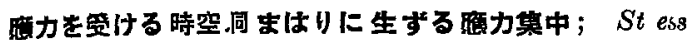

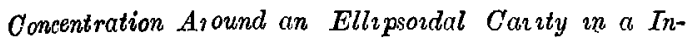
finte Body under Arbutrary Plane Stress Per pendicular to the Axis of Rezolution of Cavity, M A Sadowsky and E Sternberg, J Appl Mech 14 卷 3號, 1947/ $9,191 / 121$, 回轉軸を $z$ 軸にとり無限遠に於て $\sigma_{z}=\tau_{z x}$ $=\tau_{z x}=\tau_{z y}=\tau_{x y}=0$ なる場合の應力計算を行つてるる。先 つ無限遠て $\sigma_{x}=\sigma_{y}=1$ 及び $\sigma_{x}=-\sigma_{y}=1$ の解を求め，之 を組合はせて一般解とする。そのために基楚方程式 $\Delta *$ $=\frac{1}{2 v-1}-\frac{\partial e}{\partial x}, \quad \Delta v=\frac{1}{\Delta v-1}-\frac{\partial e}{\partial y}, \quad \Delta v=\frac{1}{2 v-1}-\frac{\partial e}{\partial z}$, $e=\frac{\partial n}{\partial x}+-\frac{\partial v}{\partial y}-+\frac{\partial w}{\partial z}$ の一般解力， $[u, v, w]=\frac{1}{2 G} \operatorname{grad}$ i, $[u, v, w\rceil=\frac{1}{G} \operatorname{cur}\left[[0,0,0],[u, v, w]=\frac{Z}{2 G} \operatorname{grad}\right.$ フ $-\left[0,0 \frac{3-v}{2 G} \lambda\right], \quad \Delta p=\Delta 0=\Delta ?=0$ の重覈て得られるの を利し，回轉棈圆座標に移り， $\sigma_{x}=\sigma_{y}=1$ 若しくは $\sigma_{x}=$ $-\sigma_{y}=1$ の一樣應力分布に, 無限遠の萑力分布を穊さな い三つの獨立解を積重ねて空洞まはりの隼力を消す。數 值計算を行ひ若干の圖表が附して京る。(玈冿)

亘交異方性中性圆墙の膨;閏，The Swelling of an $\mathrm{O}_{2}$ thotropue Curcular Tube, C. Gurney and A Hammond; J App Mech 14 卷多號, 1947/9, 18\$/190,

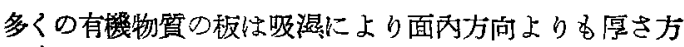

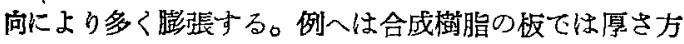
向は面內方向のらー 10 倍つ膨張を示す。故に有機物質て 作られたものは吸昆すると憵力を發生する。本論文ては 中空圆擣について理論を展開し plastıc bushing につい ては數値計算を行つている。(雾㡽)

疲勞强度と减衰とを考覀に入れた共振部材の新設計基 瓷式, A New Fatrgue St enth-Damping Criterion for the Desagrn of Resanant rembe s. Teseph Marm and FB Stulen $\mathbf{J}$ Appl Mech 14 卷 3 號, 1947/9,

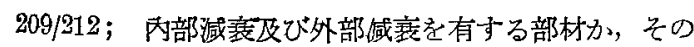
共振振動數附近の繰反乙荷重它受ける時，疲第と心ら啙 から見て許容し得るその繰这し荷重の大いさを定める公

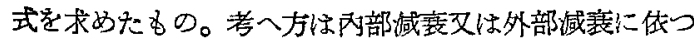
て散逸さ机るェネルギー $\Delta W$ 及は $\Delta W_{e}$ か，荷重のなす 仕事 $\Delta W_{1}$ に等しい，郎ち $\Delta W ， \Delta W_{e}$ 又は $\Delta W+\Delta W_{e}$ $=\Delta W_{2}$ といふととに在る。これに依つてある繰这し荷 董の下の振幅を定わ，次いてそれか疲等限度を越えない，

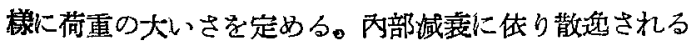
ェネルギーとしては實瑍式 $\Delta W=\int c_{1} \sigma^{2} d V$ を探用してる

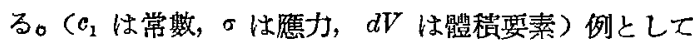
は唯，一端に集中繰远し荷重を5ける矩形断面の片持染 のみを取扱つてるる。(大島信德)

穖械的過渡現皇分析器を使用した一般振動の解析, Generalized Vibration Analysis by Means of the Mechancal Transzents Analyser, G D Mc Cann and J M Kopper, J Appl Mech 14卷 2號， 1947/6，127/134，自由度 二つの機珹的振動系—線型て且つ粘性を件ふ一一强

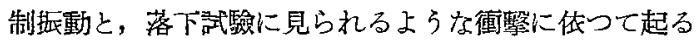
過渡現象を分柝器に依つて，振動系のパラメーターを種 々に變へた場合に就いて解いてある。分柝器は電氯的類

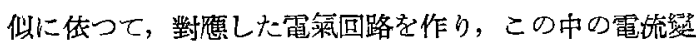
化の測定に依つて，元の機栈的振動桑の拆幅を得るもの てめる。各場合の雷流變化の賏值と，それから導かれる 原珢動采の共振曲線及び過渡的振動の曲線の圖か多数の せられてるる。(大島)

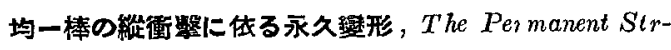
ain in a Uniform Bar Due to Longatudinal Impact, MP White and Le Van Griffis, J Appl Mech 14 委 4 號, 1917/12, 397/\%3，均一な斷面てプラステイッ クな材質から出來てるる長い棒の一端に，まる時間衝挐 的に荷重が作用した場合に起马永久絴形の分布の問題を とり报つてるる。その方失は複雜な数學的方法に低る敘 述てはなくて，繇形の波動的傳播速度の速速から巧妃に

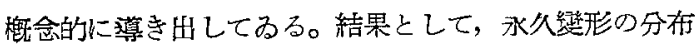
は，端から步る一定の距離入間一定て，その次のむる距 離の間减少し，再びむる一定つ距離の間一定て，次に及 减少するといふふふっに繰返され，最後に彈性哏界に相當 する應力の所で突然消える。(大島)

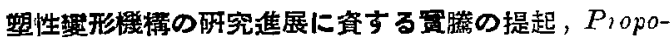
sed Expertments for Furthur Study of Mechanism of Plastic Deformation, J\& Koehler and F Seltz, J Appl Mech 14卷 3 俖, 1947/9, 217/294，この理論て 以塑性㢣形は dislocation と呼はれる結晶いいびつ(1mperfection の生成と邁動の結果てあると假定し，その

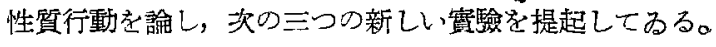

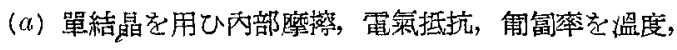
冷間加工度, 結晶方位 (crystallographic orientation) の函欺として㖇定する。(b) 細い單結晶の線て應力歪曲 線志即定する。（c）規則正しい配列を有する（well or-

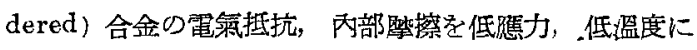
於て㑡定する。(称侓) 


\section{構 造 力 學}

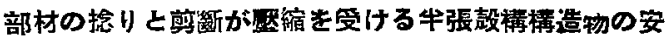
定に及ほす効果, Torsen and Shear Effects of Members upon General Instabuluty of Semumonocoque structu es under Compression Tsun kuei Wang, Sıan; J Appl.

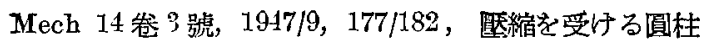
殻の挫屈に於ける框と縱通材の曲げ及び捻り，外皮の煎 斷の影響をェネルキー法を用ひて研究し，捻り及び煎斷 の効果は無哯し得ないと远べてるる。框, 縱通材には有

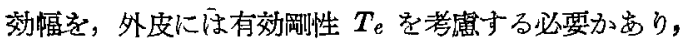
後者の決定には N J Hoff and BA Boley “The Shean ing Rigedaty of Curved Panels under Compression" TN No 1090 NACA 1946 年 8 月を參昭する。計算結 果は脞屈波形を $w_{1}=\sum \sum A_{m n} \cos n \phi \sin \frac{m \pi x}{L}, w_{t}=\Sigma \Sigma$ $\frac{A_{m n}}{n} \sin n \phi \sin \frac{m \pi x}{L}$ と假定すると $P_{R}=\frac{n^{2}}{1+n^{2}}\left[\left(1+\frac{\lambda}{n^{2}}\right)\right.$ $\left.m^{2}+\mu \frac{\left(n^{2}-1\right)^{2}}{m^{n}}+\nu \eta^{\circ}+\frac{\eta}{n^{2}}\right] こ ১ に 〉=\frac{I_{s t}}{I_{s i}}, \mu=\frac{E_{f} I_{f}}{\pi^{4} E_{s} I_{s r}}$ $\frac{c}{\bar{b}} \frac{L^{4}}{R^{4}}, \quad \vartheta=\frac{G_{p}}{\pi^{2} E_{s}} \frac{t c L^{2}}{I_{s r}}, \quad v=\left(\frac{G_{j} G_{r}}{\pi^{2} E_{s} I_{s 1}} \frac{c}{b}+\frac{K_{s} G_{s}}{\pi^{2} E_{s} I_{s 1}}\right) \frac{L^{2}}{R^{2}}$, $P_{R}=P / P_{e u l}, P_{e u}^{\prime}=\pi^{2} E_{s} I_{s r} / L^{2}, r$ は半俓方向, $t$ は切

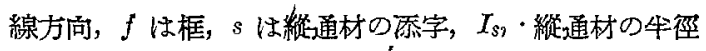
方向の謴性能奉， $I_{s t}$ 同切線方向， $\mathrm{c}$ 縱通材の圓周間隔， $b$ 框距離， $L$ 圓柱の長さ， $R$-圓桂の牛祎， $\boldsymbol{t}$ 板厚, $K_{f} G_{f}$ 框の捻り剛性, $K_{s} G_{s}$ 縱通材の捻り㓮性。末尾 に圖表を附し設計に便ならしめてるる。表題の general instabilıま といふ心言葉はすべての部材か，同時に挫屈す る意味に使用してるる。(管聿)

\section{化 學 I 學}

高度に農樎された過酸化水素の物理的及び化學的性侗， Highly Concentrated Hydrozen Peroxide; Phy sical and Chemical Properties, ES Shanley \& FP Greenspan Ind Engng Chem, 39 卷 12 號, 1947/ 12，1536/1549，90\% $\mathrm{H}_{2} \mathrm{O}_{2}$ の安定性を觸媒と安定劑と の兩方面から檢討乙，高猜度 $\mathrm{H}_{2} \mathrm{O}_{2}$ の代表的な反㷳の有 機合成，漂白，重合及び爆登技術えの應用志論し，災害 の起る可能性に關して取投々方を例示した。い僼い， $\mathrm{H}_{2} \mathrm{O}_{2}$, 列えは $90 \%$ \%のは甚た安定てある。分解は $\mathrm{H}_{2} \mathrm{O}_{2}$ (ガ ス) $\rightarrow \mathrm{H}_{2} \mathrm{O}($ ガス $)+\frac{1}{2} \mathrm{O}_{2}$ (ガス) K從い, $\Delta H=-23$ $\mathrm{kcal}, \Delta F_{288}=-30 \mathrm{kcal}, \log K_{289}=215$ にようて分解 えの勢力は大きいが，䑤觸媒の時には分解速度は顔る小

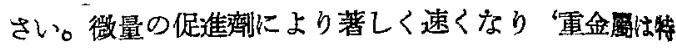

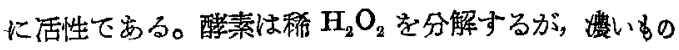
には罢される。 $\mathrm{H}_{2} \mathrm{O}_{2}$ 液は酸性て安定だが, $\mathrm{Ca}, \mathrm{Pb}, \mathrm{Mn}$ Co 等の微量により，分解率は每年 1 2\%名ら每週數\%

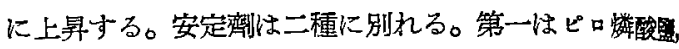
弗化物，青化物及び 8ーヒドロキシキノリン，アセタ二 リドの樣な有機化合物て，鍺イォンを作つて重金屬1木 ンを夜から除く力のあるるの，第二は新に沈淑させたす ルミテ,シリカ, 含水・酸化アンチモン, 含水酸化錫の 樣な吸着力の方るすのある。溶液か不曹の事故て污九

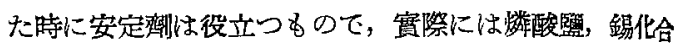
物或はその爾㨋を件用乙，液の純度の向上に主力注く。 濃 $\mathrm{H}_{2} \mathrm{O}_{2}$ はエタノール，イソプロパフール，アセ卜ノ, ×チルセロソルブ，ピリデン等と混合し，任意量の水之 湿る。水上りあ有機溶劑に溶け易い。アルコール，ヶト ン，砂糖等の溶液は静止時には安定でするが，條件によ り激しく爆發する。透電恒数は35\%水溶液て最高の 120 となり，90\%棭で $0^{\circ} \mathrm{C}$ に 297 となり，良好なイネノ化

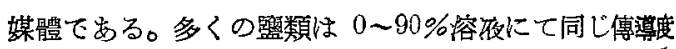
一を有することが確められた。・ $\mathrm{H}_{2} \mathrm{O}_{2}$ (液) $\rightarrow \mathrm{H}_{2} \mathrm{O}$ (夜) $+\frac{1}{3}$ $\mathrm{O}_{2}$ (ガス) +28450 cal に從之は, $90 \% \mathrm{H}_{2} \mathrm{O}_{2}$ のl は 589 $\mathrm{g}$ の $\mathrm{O}_{2}$ と $81 \mathrm{~g}$ の水蒸氮を發生する。斷埶すれば 750 ${ }^{\circ} \mathrm{C}$ となり，1 氣堅下にその温度て $5,000 l$ の容䖽を占め

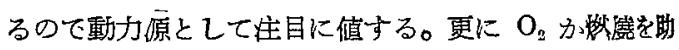

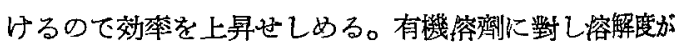

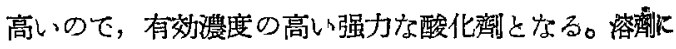
より酸化力の調節かてき，脂肪酸に溶せは過酸の酸㑃

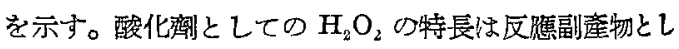
て水のみを殘すことて，染科，香科，食品の場合に有利 でる。ベンゾール，ナフタリン绫導體からキノ人置换 體を，キノソンからキノリン酸を製する時には醉酸溶湤

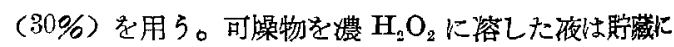
は安定たか, 刺䇅により爆發する。 $\mathrm{C}_{2} \mathrm{H}_{8} \mathrm{O}_{3}+7 \mathrm{H}_{2} \mathrm{O}_{3} \rightarrow 3$ $\mathrm{CO}_{2}+11 \mathrm{H}_{2} \mathrm{O}$ により最大感度の混合物力得られる。接稆 面て酸化力か大きいから，容解度に關係なく酸化力蜰く，

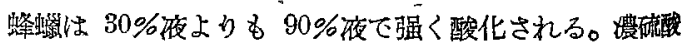
及で氷醋は無色となる。ビニル柔化合物ゆ乳化重合例へ はブナS，スチレン及びメチルメタアクリレートの重合

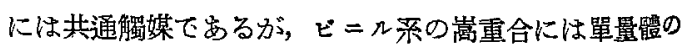
溶解度により制限され，30\%液は用いられないので，過

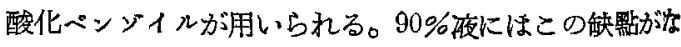
い。チオコール學の部分重合した多硫化物の拁硫に有效 


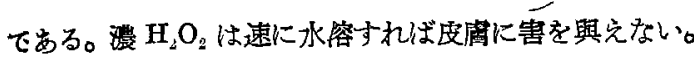
$65 \% \mathrm{H}_{2} \mathrm{O}_{2}$ は分解して生成与る水を全部蒸能寸るに充分

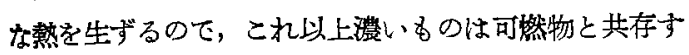
れば發火することがる。90\%ては $750^{\circ} \mathrm{C}$ に羍するのて 引以するが，触媒かなければ綿取は水を與へて子發火乙 ない、水銀塞㜪計は用ひられない。被酸化物力 $\mathrm{H}_{2} \mathrm{O}_{2}$ に よく溶けて分散する場合には危險て亦る。90\%夜の長期 販藏には新度 $996 \%$ のアルミニウム容器がよく, 稀いり 一ダ，水及び酸てよく洗う。10\%硫酸て數特間處理し， 蒸溜水て洗い最後に $\mathrm{H}_{2} \mathrm{O}_{2}$ て洗う。少量の特はガフス壻 かよく，監化ポ リビ =ルの可撓性容器か時に用いられる。 フルミニウ'ム製の管, ポンプ, 征器, ガラス器か用いら れ，監化ボリビ=ルのパッキングをつけたフランヂか好 浧与る。(山崎款共)

中華民國産桐油よりの自動車燃料，Chrnas MlQtor Fuels from Tung Oul, Chra-Chn iChang \& Shen-Wie Wan Ind Engng Chem; 39 卷 12 號, 1917/12, 1543/ 1518 , 植物油石䌞つ熱分解, 或は植物油その6のの熱分 解又は接觸分解により肪脂酸は炭化水素に愁る。戰特中 中華民國ては植物油から自動車然科をとるために不連䋉 分解丢か行われ，主として輸出てきなかつた桐油を原紏 にした。原桐油の 70 容量\%の粗油力得られ，粗油のガ

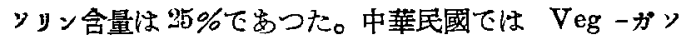
リン及びーデーゼル油と栲し，循環資料よりの然科とし て重視された。不畧熱分解。住て得たガンリンの狹い瑠分 中に次の炭化水素高認めた。

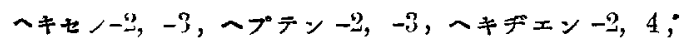
ヘプタチェン -2，4，メキルシクロペンタン；シクロペ ンタノ；メチルシタロペンダン，シクロオクタン。生產

ガ

\begin{tabular}{|c|c|c|c|c|c|c|c|c|c|c|}
\hline & \multirow{2}{*}{ 包調 } & \multirow{2}{*}{$\begin{array}{l}\text { 比重 } \\
\left(\mathrm{d}_{18} \mathrm{~s}\right)\end{array}$} & \multirow{2}{*}{ 酸傊 } & \multirow{2}{*}{ 痛蝕泩 } & \multirow{2}{*}{ 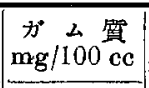 } & \multicolumn{5}{|c|}{ ASTM 蒸溜 } \\
\hline & & & & & & 初溜 & $10 \%$ & $50 \%$ & $90 \%$ & 終玨占 \\
\hline 中華戒圆政府 & 炎黃 & $<0800$ & $<020$ & - & 150 & 65 & 85 & 135 & 200 & 225 \\
\hline Veg 油管凖 & 炏黃 & $<0790$ & $<\begin{array}{lll}0 & 08\end{array}$ & - & $2^{-}$ & 60 & 86 & 132 & $2 \cup 5$ & 215 \\
\hline
\end{tabular}

チーゼル油

\begin{tabular}{|c|c|c|c|c|c|}
\hline & API & $\begin{array}{l}\text { 粘 }{ }^{\circ} \text { 度 } \\
100^{\circ}\end{array}$ & 酝 價 & 炭素旌溑 & 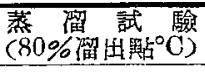 \\
\hline 韩 油 & 350 & 88 & 050 & $<0^{2}$ & $<90$ \\
\hline 中華民圈政府 & 270 & 45 & 050 & $<02$ & $<350$ \\
\hline 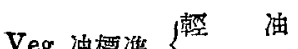 & 350 & 36 & 040 & - & $<300$ \\
\hline Veg 伷槽华 精 製 伷 & 270 & 43 & 040 & 一 & $<3,50$ \\
\hline
\end{tabular}

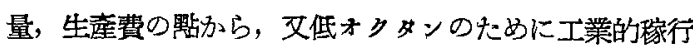
は困難てある。同國工業研究局の Veg 燃料規格と比較 すれば下表の焃になる。(山崎)

フイッシャー・トロプシ合成, 常區におけるコバルト 觸媒の試豴，Evscher-Tropsch Synthesus, Tests of Cobalt Catalysts at Atmosphernc Pressure R B Anderson, A Kkieg, B Seligman \& W E O'Neill, Ind Engng. Chem 同上，39卷 12 號，1947/12，1548/1564，代表 的な Co 觸桇の調製及び試嚷について这へた。同一觸媒 トの試驗は再現性のある結果を與えるか，同樣に調製した

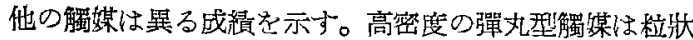
のもよりも輕質枈化水素及び $\mathrm{CO}_{2}$ を多く生成するの てよくない。彈丸型觸媒は同一容樻で同一の血度及び衏 化率て粎，倍の合成がスを處理することかてきるのて， この缺點仿補われる。但乙反應熱る除去する能力て自然 に抑えられる。合成ガスの流速を翋え，同一專換率を與 える桹に溫度を調節して試驗した。流速及び罝度の上昇

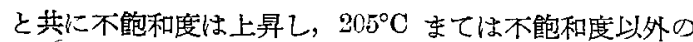
性質は本質的に同じです。合成の全后性化エネルキー は 24〜27 kcal/モ几ですることを認めた。不飽和度が 溫度及び流速で警ることは低級炭化水素に甚たしい。臭 素價は宾間容積か6 倍になると 5 倍になるか，最大臭素 偠の不飽和生成油は臭素價 30 に過ぎない。(山崎)

商望反㢈, High Pres‘u e Reactions, E L Clark, P L Golden, A M Whitehouse \& H H Storch, Ind Engng Chem 39卷 12號, 1947/12，1555/1564，合成 夜體燃料傆として，石炭の水素潶加の研究裝置に閜する 設計及び取扱い业は，多くの菏酷な操作を求め的尚の

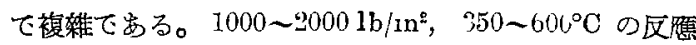
條件に加えて生成物の滕創性加

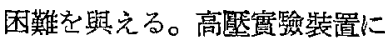
三種の型かるり，不連瀆式或は 反應體及び生成體が移動しない あの，これらの一部か移動する 牛連端式及び原料仕达玉れて 製品が出される連橲式かこれて ある。從業員の倍險在防止する 點充も考膚に入れた裝置の設計 について多くの㮔討を加え，杪 質, 容器の開閉, 內張り，操作 技術，不連結式の調整佉等につ いてむ述へてるる。高病蝕泩物 


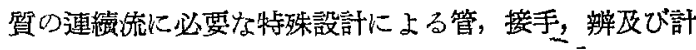
器類についても述へ，ドィンで規期の坐工業試譣て用 いられた裝置と，アメリカ鐄山局のそれとを比較した。 (山崎)

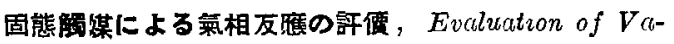
poun Phase Reactions wath Solnd Cutalysts, H J Henriques, Ind Engng Chem 39卷 丁2號, 1947/12, 1564/ 7570 ，少量の試料と觸某を用いて接触反㕍を研究するた めには精度を保つ上から特殊の裝置と操作か必要てある。 この目的には一般市販のボンプ统量計及び他の附屬品は

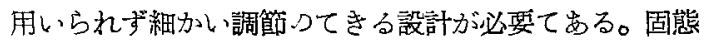

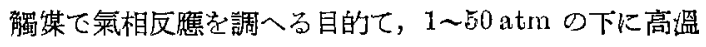
て實镝てきる裝置について速べている。(山崎)

高分子量附加重合體の褧造，Prepcuation of $H_{2} g h$ Molecular Wezglit Addition Polymers A I Goldberg; Ind Engng. Chem 89卷 1: 號, 1917/1， 1570/1573,

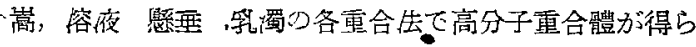
れるが，贸置は單體の物理性によつて支配される。登垁 反隹て省るから，平均分子量と同し程度に反應の盜度調 節さ重要てする。從つて生成物の物理性は盕度によつて かなり资化する。熱傳導及ひ攪汼の良好なことか必要に 在る。重合温度てがス態の軍發性單體か多數存在するの

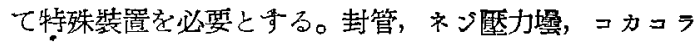

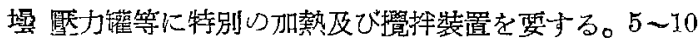

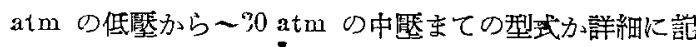
されてるる。喗發性單體の取扱，重合體の分朔及び低溫

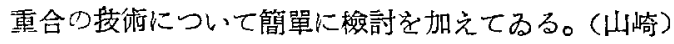

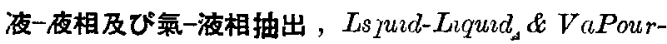

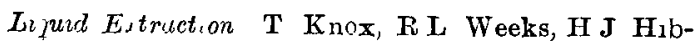
sman \& JH Mc Ateer, Ind Engng. Chem 89卷,

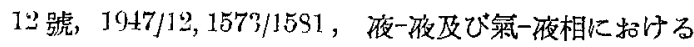
連續又は不連得抽出の研究に用いる抽出裝置について詳 䊽に記載し，代表的なデータによつて操作技術について

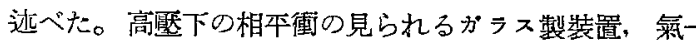
液相抭出の研究に出いられる不連續裝置，夜一夜相抽出 に扣ける向流及び抽出塔裝置，贸一夜相抽出に對する向 流式抽出塔について記されている。(山崎)

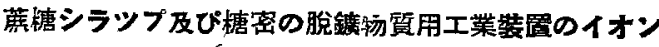
交換喿作, Ion exichange Operation of Commercial Secble Plant for Demineralization of Cane Sirups \& Malasse;, E Bloch \& R J Ritchie, Ind Engng Chem 39 参 12號，1947/12， J581/10ั84 簏榶ンラップ及び轉化糖
泌を棈製するためにイオン交換法により鎕物椞を除くエ 場か、運轉を始めた。この裝置はイオン交換部，粒狀罗床 及び陰イォン交換部からなる。部分的に猼化した工業的

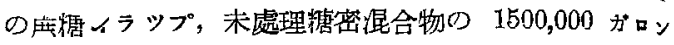
及び青登の不完全な轉化糖密 715,000 ガロノを處理する ために，4 基か用いられる。困難の第一は陽イォン交换 床にゴム質の皮膜か生し，そのために海體の流れを妨げ，

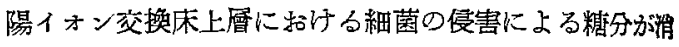
失することてもる。この裝置て粗栯婆か、食用ンラップ

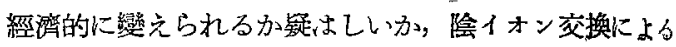
有機酸の回收を考它粗糖及び部分的に精製された糖の腋 龲物質にこれを用いることを考えた。(山崎)

高純度の炭化水素の贸造に暖着の利用, Adso1 ption, $A$ Tool an the Prep sration of High Purty Saturated Hy. drocaibons, A E Hirschler \& S Amon, Ind Eagng. Chem 39 卷 12 號, 1947/12，1585/1596，鵤和炭化水素 の異性體绲合物はンリカゲ几及は活性桨の吸着によつて 分離てきる。パラフインーパラフイン，パラフインテナ テン及びナフテシーナフテン型の二成分采合成混合物の 分別热行つた。多くのこれらの混合物はンリカゲルては $S$ 型の，舌性炭ては $U$ 型の等溫吸着曲線を與える。炭

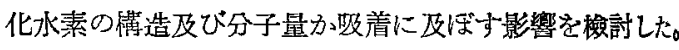
成績については Fieundlıch の吸着等溫曲線によつて説 明てきる。工業的の或は合战炭化水素混合物加ら純䢂物 加分離される，5，2，2-トリメキルペンタン及び，2， タートリメチルブタンか他の如何なる方佉よりる良い純度 て得られた。不飽和及び高分子量炭化水素吸着により

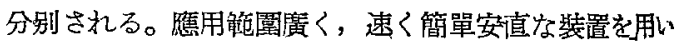
るこの方去は飽和灰化水素の分離及び棈製に對して最も 强力，便利な道具て怘る。吸善㹤は屈折率と共に，維度 の詔定に有用て，融坫の容易に求められない发化水素に 對して特に有力てある。活性炭及びンリカゲルの兩方を 通したものの性質は各々を通つたもの上り純度の登服 役立つ。(山崎)

高沸哭の液體及びモの露の引火性，Flammabrlity of the Hugher Bouling Liquits \& therv Mrsts, M V Sull-" ivan, $J \mathbf{K}$ Wolk \& W A Zisman Ind Engng Chem 39 卷 12 號，1917/12，1607/1614；大氣中に油滴为存在

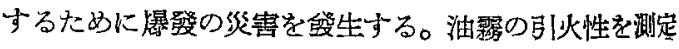
する贸置を考案し，多くの夜體に㷳用した。これらの液

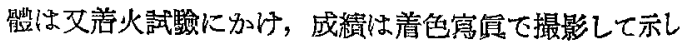
た。(阳崎) 